\title{
Host-plant-associated genetic differentiation in Northern French populations of the European corn borer
}

\author{
C Martel ${ }^{1}$, A Réjasse ${ }^{1}$, F Rousset ${ }^{2}$, M-T Bethenod ${ }^{1}$ and D Bourguet ${ }^{1}$ \\ ${ }^{1}$ Unité de Recherches de Lutte Biologique, Institut National de la Recherche, Agronomique La Minière, 78285 Guyancourt, France; \\ ${ }^{2}$ Laboratoire Génétique et Environnement, Institut des Sciences de l'Evolution, Université de Montpellier II, 34095 Montpellier, France
}

\begin{abstract}
The phytophagous insects that damage crops are often polyphagous, feeding on several types of crop and on weeds. The refuges constituted by noncrop host plants may be useful in managing the evolution in pest species of resistance to the Bacillus thuringiensis toxins produced by transgenic crops. However, the benefits of these refuges may be limited because host-plant diversity may drive genetic divergence and possibly even host-plant-mediated sympatric speciation. The European corn borer, Ostrinia nubilalis Hübner (Lepidoptera: Crambidae), is the main pest of maize in Europe and North America, where it was introduced early in the 20th century. It has a wide host range but feeds principally on mugwort (Artemisia vulgaris L.) and maize (Zea mays L.). $O$. nubilalis is found on mugwort only in the northern part of France, whereas it is found on maize throughout France. The extent of genetic variation at allozyme markers was
\end{abstract}

investigated in populations collected from the two host plants over the entire geographical distribution of the European corn borer on mugwort in France. Allelic differentiation between pairs of populations and hierarchical analyses of pools of samples from each host plant indicate that the group of populations feeding on maize differed from the group of populations feeding on mugwort. Our results suggest (1) host-plant-related divergent selection at the genomic region surrounding the Mpi locus and (2) limited gene flow between the populations feeding on mugwort and those infesting maize fields. These data indicate that adults emerging from mugwort would not be useful for managing the evolution of resistance to the $B$. thuringiensis toxins in European corn borer populations.

Heredity (2003) 90, 141-149. doi:10.1038/sj.hdy.6800186

Keywords: Ostrinia nubilalis; European corn borer; transgenic insecticidal maize; sympatric speciation; population structuration and differentiation

\section{Introduction}

The theory that new species may evolve despite gene flow has recently gained theoretical support (Schluter, 1998; Tregenza and Bridle, 1998; Dieckmann and Doebeli, 1999; Kondrashov and Kondrashov, 1999; Kirkpatrick and Ravigné, 2002) and has been accompanied by an increasing number of examples of sympatric host races (eg Emelianov et al, 1995; Via, 1999; Groman and Pellmyr, 2000). The influence of ecological factors in speciation has also recently been emphasized (Schluter, 1998; Schilthuizen, 2000; Via, 2001). For example, the selective use of diverse resources may lead to the evolution of ecological specialization and adaptation (Berembaum, 1996; Kawecki, 1997). This has been demonstrated in herbivorous insects feeding on a wide range of host plants: colonization of a new host may induce the selection of adaptive characters and population genetic differentiation (Rice, 1987; Diehl and Bush, 1989). Phenological, phytochemical and morphological differences between host plants may promote genetic isolation

Correspondence: D Bourguet, Unité de Recherches de Lutte Biologique, Institut National de la Recherche, Agronomique La Minière, 78285 Guyancourt, France. E-mail: bourguet@jouy.inra.fr

Received 21 January 2002; accepted 19 August 2002 following host shifts - a first step toward speciation (Bush, 1994).

Here, we show that the European corn borer (ECB, Ostrinia nubilalis Hübner) may provide an interesting example of genetic divergence of sympatric host-plant populations. ECB is native to Europe, North and West Africa (Mutuura and Munroe, 1970) and was introduced into North America early in the 20th century (Hudon et al, 1989). Owing to its economic importance - ECB is the main pest of maize, causing estimated yield losses of $\sim \$ 1$ billion per year in the US (Ostlie et al, 1997) — this species has been extensively studied over the last century (review in Hudon et al, 1989).

A few studies have focused on population genetics of the ECB (Harrison and Vawter, 1977; Cardé et al, 1978; Willet and Harrison, 1999; Bourguet et al, 2000a,b). However, habitat heterogeneity has been little studied. This is unfortunate because a wide variety of host plants are suitable for ECB oviposition and larval development, including many crops such as snap beans, peppers, potatoes, hops and maize (Caffrey and Worthley, 1927). In a previous study, we investigated the genetic variability of samples collected on mugwort (Artemisia vulgaris L.), hop (Humulus lupulus L.) and maize (Zea mays L.) over a restricted area in northern France (Bourguet et al, 2000b). We found that these populations did not constitute a single panmictic unit, those collected 
on maize being genetically different from those collected on mugwort and hop. However, it was unclear whether this genetic differentiation extended over a broader geographical scale.

In this study, we investigated further the genetic variability of ECB populations collected on mugwort and maize. We began by determining the geographical distribution of ECB on mugwort in France. We then assessed and compared genetic differentiation within and between samples of $O$. nubilalis collected on the two host plants throughout this area. Finally, we used a combination of mitochondrial DNA (mtDNA) sequence analysis and allozyme electrophoresis to assess the effects of host association on the genetic structure of populations and to investigate the origin of host association.

\section{Materials and methods}

\section{Geographical distribution}

The geographical distribution of the ECB, Ostrinia nubilalis, on mugwort Artemisia vulgaris was established by investigating 74 sites throughout France (Figure 1a).
At each site, we screened 100-500 stalks of mugwort for the presence of fifth instar larvae.

\section{Enzyme electrophoresis}

Sampling sites: Samples were taken from mugwort growing at 16 sites spread over the geographical distribution (Figure 1b). Individuals were collected as larvae diapausing on plants, their sex was determined and they were directly frozen at $-80^{\circ} \mathrm{C}$.

Data from former samplings on maize were used to evaluate the impact of host plant on the genetic structure of the population. Nine sites (Ger, Lor, Mes, Pic, Run and Wol, described in Bourguet et al (2000a), and Ave, Sol and Mar, described in Bourguet et al (2000b)) were chosen because their geographical distribution overlapped with the 16 mugwort sampling sites (Figure 1b).

Electrophoresis: The head was removed from each larva for further analysis and the rest of the body was homogenized in 150-200 $\mu$ l of Tris-EDTA (pH 6.8). The homogenates were subjected to horizontal starch gel electrophoresis in Tris-borate-EDTA ( $\mathrm{pH}$ 8.6) buffer systems (Pasteur et al, 1987). Six polymorphic enzymes allowing unequivocal genetic interpretation

a

European corn borer on Artemisia vulgaris $\mathrm{L}$.

- Presence

- Absence

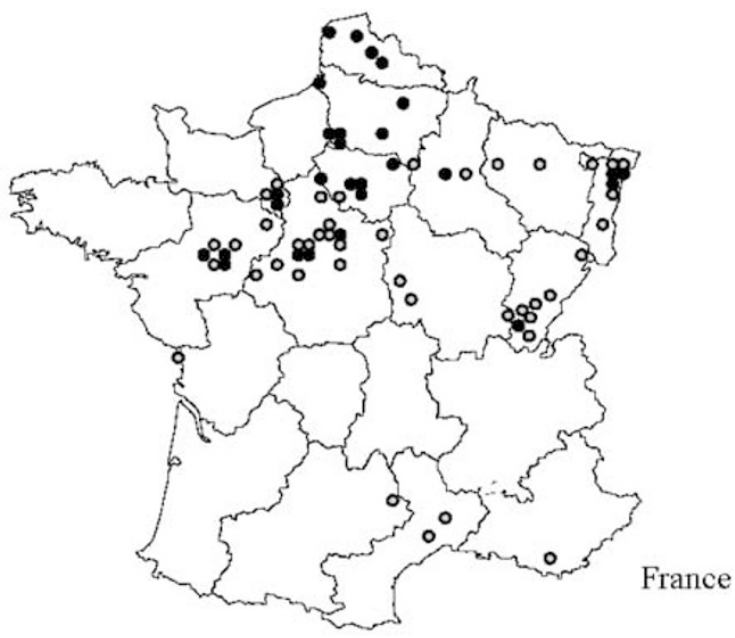

b

$\Delta$ Sampling sites on maize

- Sampling sites on mugwort

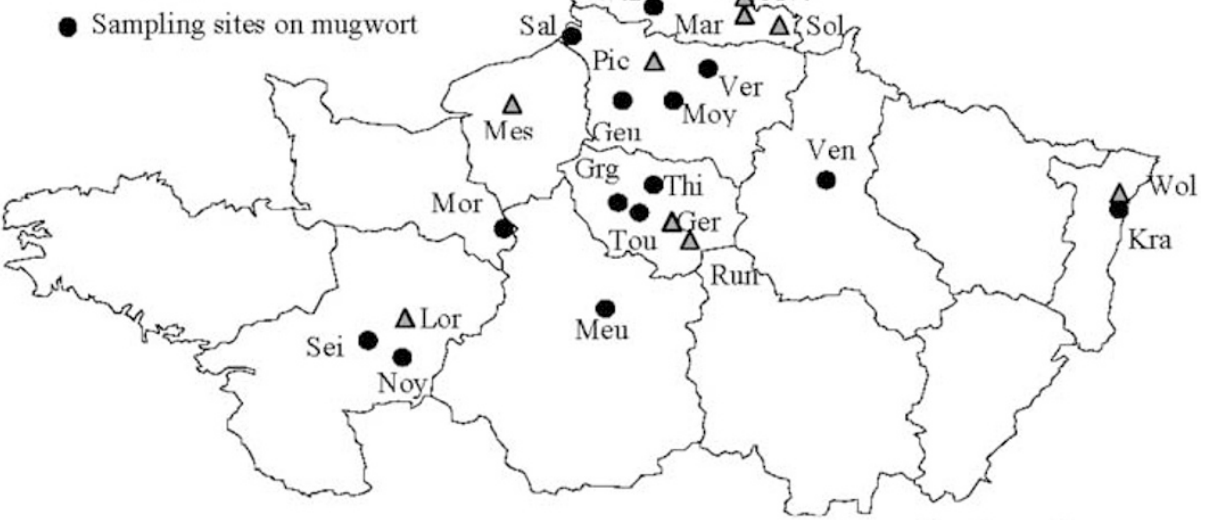

Northern France

Figure 1 Geographical locations: (a) mugwort sites investigated for the presence of the European corn borer; (b) sampling sites used for the analysis. 
were revealed as described by Bourguet et al (2000a). These enzyme systems were: phosphoglucomutase (PGM, EC8.4.2.2), mannose-6-phosphate isomerase (MPI, EC5.3.1.8), hydroxybutyrate dehydrogenase (HBDH, EC1.1.1.30), glucose-phosphate isomerase (GPI, EC 5.3.1.9), aspartate aminotransferase (AAT, EC2.6.1.1) and triose phosphate isomerase (TPI, EC5.3.1.1). Tpi is located on the $Z$ sex chromosome (Glover et al, 1990). Females are heterogametic (ZW) whereas males are homogametic (ZZ). Thus, at this locus, females are hemiploid whereas males are diploid.

Data analysis: We computed sample allelic frequencies, the mean number of alleles, the observed and expected heterozygosity and $\hat{f}$-values (ie $F_{\text {is }}$ estimates according to Weir and Cockerham (1984)) for the 16 samples collected on mugwort using Fstat 2.8 software (Goudet, 1999). We tested for deviation from Hardy-Weinberg expectations at each locus and calculated genotypic linkage disequilibrium between loci within each sample, with GENEPOP 3.2a software (Raymond and Rousset, 1995). As Tpi is a sex-linked locus, observed heterozygosity and $\theta$-values were estimated and tests for deviations from Hardy-Weinberg expectations were carried out for males only.

These results were compared with those obtained for nine samples collected on maize by Bourguet et al $(2000 a, b)$. The genetic structure between the 25 samples (16 on mugwort and nine on maize) and between samples collected on each host group (a host group includes all samples collected on a given host plant over the whole area) was analyzed by testing for allelic differentiation using exact tests and by calculating the $\hat{\theta}$ estimator of $F_{\text {st }}$ as described by Weir and Cockerham (1984), using GENEPOP 3.2a (Raymond and Rousset, 1995). In addition, we used TFPGA 1.3 software (Miller, 1997) to carry out hierarchical analyses of population structure to assess the effect of the host plant on population structure with respect to total genetic variation.

Isolation by distance patterns (Wright, 1943) was also investigated in each case by assessing the independence of geographic and genetic distances $((\hat{\theta} /(1-\hat{\theta}))$ and $\ln$ (geographical distance)) as described by Rousset (1997). The null hypothesis that geographic and genetic distances were independent was tested against an alternative hypothesis of a positive correlation, as expected under isolation by distance. We used Spearman's rank correlation coefficient as the test statistic. The calculated correlation coefficient was compared with the distribution of correlation coefficients obtained from Mantel-like permutations as implemented in GENEPOP 3.2a (Raymond and Rousset, 1995).

\section{mtDNA variations and haplotypes}

mtDNA sequence variations: Total DNA was extracted from the heads of fifth instar larvae according to the protocol described by Estoup et al (1996). We amplified a 1882 bp mtDNA region starting (position 1) at nucleotide position 267 of the cytochrome oxidase subunit I (COI) (Caterino et al, 2001) and ending (position 1882) at position 531 of the cytochrome oxidase subunit II (COII) (Kim et al, 1999), including the entire $\mathrm{tRNA}_{\text {leu. This }}$ mtDNA region was amplified for 15 individuals from three geographically separated populations (populations Car, Wol described in Bourguet et al (2000a) and population Chti described in Bourguet et al (2000b)). We identified 15 variable positions (details not shown), four of which affected restriction sites. The corresponding restriction enzymes (Sau3A, Ssp1, Vsp1 and Alu1) were used for screening and comparing mtDNA haplotypes in populations collected on the two host plants.

mtDNA haplotypes: We checked for the presence of restriction sites from position 142 to 431 (region I) for $V s p 1$, from position 452 to 1882 (region II) for Sau3A and Alu1, and from position 1096 to 1669 (region III) for $S s p 1$.

For the three regions, the PCR mixtures contained $1 \times$ PCR buffer (Eurogentec, Seraing, Belgium), $1.25 \mathrm{mM} \mathrm{MgCl}_{2}$ $0.2 \mu \mathrm{g} / \mu \mathrm{l}^{-1}$ BSA, $0.2 \mathrm{mM}$ dTNPs, 1.2 unit Taq polymerase and $1 \mu \mathrm{M}$ each primer (region I, forward: CTAATATTCTCATGGAGGT, and reverse: TAAAATAGGATCTCCCCCTC; region II, forward: TTTTGGACATCCAGAAGTTT, and reverse: CGACCTGGATTAGCATCTAC; for region III, forward: ATACCTCGACGTTATTCAGA, and reverse: TCAATATCATTGATGACCAAT). The final reaction volume was $30 \mu \mathrm{l}$ including $20 \mathrm{ng}$ of DNA template. Cycling conditions were as follows: $94^{\circ} \mathrm{C}$ for $5 \mathrm{~min}$, followed by 35 cycles of $94^{\circ} \mathrm{C}$ for $1 \mathrm{~min}$, annealing temperature for $1 \mathrm{~min}$ and $72^{\circ} \mathrm{C}(1 \mathrm{~min}$ for regions I and III and $2 \mathrm{~min}$ for region II), and then a final $10 \mathrm{~min}$ at $72^{\circ} \mathrm{C}$. The annealing temperatures were 60,57 and $51^{\circ} \mathrm{C}$ for regions I, II and III, respectively.

mtDNA haplotypes and their frequencies were investigated for 10 populations, five from mugwort sites (Kra, Sei, Tou, Ven described in Table 1 and Lef described in Bourguet et al, 2000b) and five from maize sites (Fon, Ger, Lor, Sol, Wol described in Bourguet et al, 2000a).

Data analysis: $F_{\text {st }}$ values were generated from mtDNA haplotype variation. The genetic structure of populations was investigated by an analysis of molecular variance (AMOVA) approach (Excoffier et al, 1992), using ARLEQUIN 2.0 (Schneider et al, 2000). AMOVA is essentially similar to other approaches based on analyses of variance of gene frequencies (Weir and Cockerham, 1984), but it takes into account the number of mutations between molecular haplotypes. A hierarchical analysis of variance allowed us to partition total variance into covariance components and therefore to test for population differentiation among host plants. The significance of the fixation indices was assessed with a nonparametric permutation approach described by Excoffier et al (1992) and included in ARLEQUIN 2.0 (Schneider et al, 2000).

\section{Results}

\section{Geographical distribution}

Figure 1a indicates the presence or absence of ECB on mugwort at the various sites. O. nubilalis larvae were found at 28 sites (of 74) in the northern regions of France, with population densities of $\sim 0.1$ to 1 larva per mugwort stalk. They were rare in western and eastern parts of France and, when present, population density was generally low $(<0.01$ larvae per stalk).

\section{Allozyme analysis}

For the 16 samples collected on mugwort, the $H b d h$ locus displayed no polymorphism and was therefore not 
Table 1 Characteristics of samples of $O$. nubilalis collected on mugwort, A. vulgaris: location, date of sampling and number ( $N$ ) of ECBs analyzed

\begin{tabular}{|c|c|c|c|c|c|c|c|}
\hline Region & Département & Location & Population & Latitude & Longitude & Date (month/year) & $\mathrm{N}$ \\
\hline \multirow[t]{3}{*}{ Nord-Pas-de-Calais } & Pas-de-Calais & Cap Griz-nez & Cap & $50^{\circ} 52^{\prime} \mathrm{N}$ & $1^{\circ} 35^{\prime} \mathrm{E}$ & $03 / 2000$ & 37 \\
\hline & & Wailly & Wai & $50^{\circ} 14^{\prime} \mathrm{N}$ & $26^{\prime} \mathrm{E}$ & $03 / 2000$ & 40 \\
\hline & Nord & Steenvoorde & Stee & $50^{\circ} 49^{\prime} \mathrm{N}$ & $2^{\circ} 35^{\prime} \mathrm{E}$ & $03 / 2000$ & 40 \\
\hline \multirow{4}{*}{ Picardy } & Somme & Sallenelle & Sal & $50^{\circ} 11^{\prime} \mathrm{N}$ & $1^{\circ} 38^{\prime} \mathrm{E}$ & $02 / 2000$ & 38 \\
\hline & Aisnes & Vermand & Ver & $49^{\circ} 52^{\prime} \mathrm{N}$ & $3^{\circ} 09^{\prime} \mathrm{E}$ & $03 / 2000$ & 40 \\
\hline & Oise & Geulancourt & Geu & $49^{\circ} 22^{\prime} \mathrm{N}$ & $1^{\circ} 47^{\prime} \mathrm{E}$ & $03 / 2000$ & 28 \\
\hline & & Moyvillers & Moy & $49^{\circ} 26^{\prime} \mathrm{N}$ & $2^{\circ} 46^{\prime} \mathrm{E}$ & $03 / 2000$ & 40 \\
\hline \multirow[t]{3}{*}{ Ile-de-France } & Yvelines & Grignon & Grg & $48^{\circ} 51^{\prime} \mathrm{N}$ & $1^{\circ} 55^{\prime} \mathrm{E}$ & $03 / 2000$ & 39 \\
\hline & & Toussus & Tou & $48^{\circ} 45^{\prime} \mathrm{N}$ & $2^{\circ} 07^{\prime} \mathrm{E}$ & $02 / 2000$ & 40 \\
\hline & Seine et Marne & Thieux & Thi & $49^{\circ} 01^{\prime} \mathrm{N}$ & $2^{\circ} 40^{\prime} \mathrm{E}$ & $03 / 2000$ & 20 \\
\hline Basse-Normandie & Orne & Mortagne & Mor & $48^{\circ} 31^{\prime} \mathrm{N}$ & $0^{\circ} 33^{\prime} \mathrm{E}$ & $04 / 2000$ & 40 \\
\hline \multirow{2}{*}{ Pays de la Loire } & Maine-et-Loire & Seiches & Sei & $47^{\circ} 35^{\prime} \mathrm{N}$ & $0^{\circ} 22^{\prime} \mathrm{W}$ & $04 / 2000$ & 29 \\
\hline & & Noyant & Noy & $47^{\circ} 31^{\prime} \mathrm{N}$ & $0^{\circ} 08^{\prime} \mathrm{E}$ & $04 / 2000$ & 14 \\
\hline Centre & Loiret & Meung & Meu & $47^{\circ} 49^{\prime} \mathrm{N}$ & $1^{\circ} 35^{\prime} \mathrm{E}$ & $02 / 2000$ & 40 \\
\hline Champagne-Ardenne & Marne & Venteuil & Ven & $49^{\circ} 02^{\prime} \mathrm{N}$ & $3^{\circ} 58^{\prime} \mathrm{E}$ & $03 / 2000$ & 40 \\
\hline Alsace & Bas-Rhin & Obernai & Kra & $48^{\circ} 28^{\prime} \mathrm{N}$ & $7^{\circ} 30^{\prime} \mathrm{E}$ & $03 / 2000$ & 24 \\
\hline
\end{tabular}

Table 2 Hierarchical $F_{\text {st }}$-values based on genetic variations at allozyme loci and mtDNA

\begin{tabular}{|c|c|c|c|c|c|c|c|}
\hline & \multicolumn{6}{|c|}{ Allozyme loci } & \multirow[t]{2}{*}{$m t D N A$} \\
\hline & Tpi & Gpi & Aat & Mpi & Pgm & All & \\
\hline$F_{\text {st }}$ - overall & $0.045^{* * * *}$ & $0.032^{* * * *}$ & $0.016^{* * * *}$ & $0.091^{* * * *}$ & $0.034^{* * * *}$ & $0.048^{* * * *}$ & $0.042^{* *}$ \\
\hline$F_{\text {st }}-$ host & 0.001 & $0.018^{* * *}$ & 0.003 & $0.122^{* * * *}$ & $0.015^{* * *}$ & $0.044^{* * * *}$ & 0.003 \\
\hline$F_{s t}-$ within mugwort ${ }^{\mathrm{a}}$ & $0.067^{* * * *}$ & $0.041^{* * * *}$ & $0.014^{* * * *}$ & $0.040^{* * * *}$ & $0.025^{* * * *}$ & $0.036^{* * * *}$ & 0.038 \\
\hline$F_{\mathrm{st}}-$ within maize & 0.003 & -0.002 & $0.018^{* * *}$ & 0.013 & $0.032^{* * *}$ & $0.009^{* * * *}$ & $0.039^{*}$ \\
\hline
\end{tabular}

aValues were calculated independent of the hierarchical calculation. ${ }^{* * *} P<10^{-5}$, ${ }^{* * *} P<10^{-3}$, ** $P<10^{-2}$ and ${ }^{*} P<5 \times 10^{-2}$.

included in the analysis. The allelic frequencies at the five other loci (Tpi, Gpi, Aat, Mpi and Pgm) for each population are given in the Appendix. We found no significant genotypic association between any pair of loci over the 16 sample sites.

Within samples, the mean number of alleles was 2.203.40 for the five loci tested. The observed and expected heterozygosities were almost identical and were 0.20 0.41 (observed) and 0.18-0.41 (expected). These values did not differ significantly from those for samples collected on maize, for which the mean number of alleles and the observed heterozygosities were from 2.20 to 3.20 and from 0.23 to 0.32 , respectively (Bourguet et al, $2000 a, b)$.

Separately analyzed, the populations showed a weak deficit of heterozygotes (14 of 16 populations), but these deviations from Hardy-Weinberg expectations for the five loci were not significant if multiple testing was taken into account (Bonferroni test, Holm, 1979). The $\hat{f}$-value estimate calculated over the sampling sites indicated a significant deficit of heterozygotes $(\hat{f}$ total $=0.065$, $P=0.0044)$. This deficit was significant for two of the five loci investigated (Tpi, $P=0.0045$ and Mpi, $P=0.0437)$.

Tests of allelic differentiation between pairs of samples for each locus (details not shown) identified four samples (Sei, Kra, Mor and Sal) with genetic structures different from the others. Finally, there was significant differentiation between the 16 samples collected on mugwort $\left(P<10^{-5}\right)$ but the mean $\hat{\theta}$-value was low $(\hat{\theta}$-within mugwort $=0.036$; see Table 2). However, the level of differentiation was higher than that for the nine samples collected on maize in the same geographical area $(\hat{\theta}$ within maize $=0.009$ and $P<10^{-5}$; see Table 2 ).

The overall differentiation between the 25 sites $(\hat{\theta}$ overall) was 0.048 , a value significantly different from 0 (Table 2). Hierarchical analysis indicated that the distribution of genetic variability was significantly influenced by the host plant $\left(\hat{\theta}\right.$-host $=0.044 ; P<10^{-5}$; see Table 2).

Genetic differentiation between the two host-plant groups can be further investigated by comparing withinand between-group isolation by distance patterns (Rousset, 1999a). Mantel-like tests were carried out to assess the independence of geographic and genetic distances, for all loci and then again for all loci except Mpi as this locus showed the highest level of differentiation between the two host plant groups (Figure 2). The isolation by distance pattern was not significant for the maize group (slope $=0.0020, P=0.142$ when considering all loci; slope $=0.0021, P=0.237$ if $M p i$ was excluded from the analysis). Conversely, a significant isolation by distance pattern was found for the mugwort group (slope $=0.0163, P=0.004$ when considering all loci; slope $=0.0212, P=0.001$ if $M p i$ was excluded from the analysis). Outliers were not responsible for this pattern because the regressions remained significant if extreme values were excluded. When considering all loci, between-group differentiation was not correlated with distance (slope $=0.0029, P=0.525$ ) and was higher than 


\section{Isolation-by-distance}

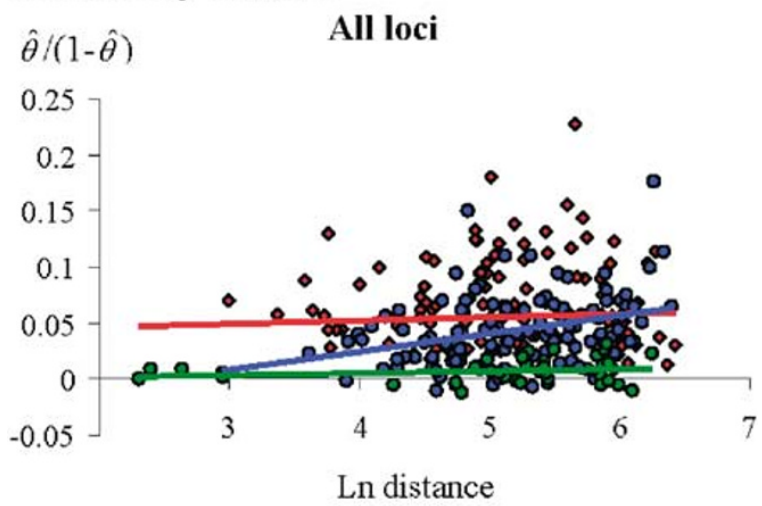

$\hat{\theta} /(1-\hat{\theta}) \quad$ All loci except $\mathrm{Mpi}$

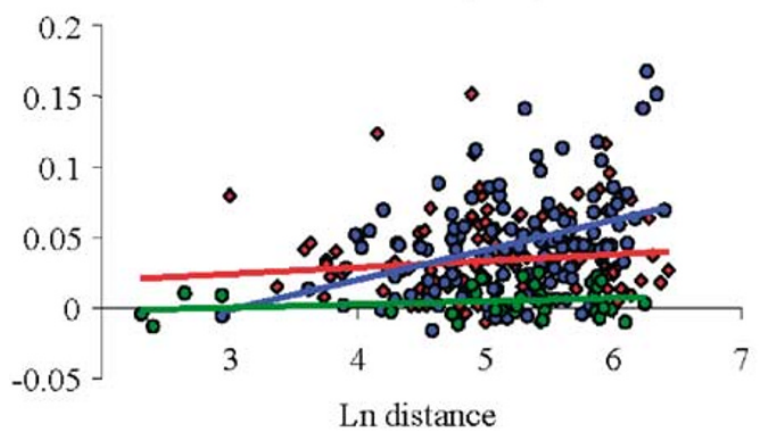

- Between-groups ○ Within mugwort group

- Within maize group

Figure 2 Regressions of $\hat{\theta} /(1-\hat{\theta})$ against $\ln$ (geographical distances) $(\mathrm{km})$ for populations collected on Artemisia vulgaris (within mugwort), on Zea mays (within maize) and between populations collected on the two host plants (between-group). Regressions are given for all loci and for all loci except the Mpi locus.

within-group differentiation at all distances. If $\mathrm{Mpi}$ was excluded from the analysis, between-group differentiation remained independent of geographical distance (slope $=0.0043, P=0.170$ ) and was still higher than within-group differentiation at short distances (see Figure 2).

\section{Mitochondrial analysis}

We found 14 restriction sites but only four of them (at nucleotide positions 258, 566, 1114 and 1139) were informative. We were able to define six $m t \mathrm{DNA}$ haplotypes over the 254 individuals collected at the 10 sampling sites. One of these haplotypes was predominant at all sites and fixed at four (details not shown). The number of haplotypes per site was small and similar for populations collected on mugwort (mean \pm $\mathrm{SE}=1.60 \pm 0.55)$ and maize (mean $\pm \mathrm{SE}=2.00 \pm 1.00)$. Maximum likelihood analysis of all the unique haplotypes for each population failed to reveal genetic structure corresponding to host affiliation. AMOVA showed that if genetic distances (calculated from pairwise differences) between haplotypes were combined with haplotype frequency, the variation was either distributed throughout all populations or corresponded to within host-plant groups rather than between hostplant groups (Table 2).

\section{Discussion}

Geographical distribution

In Europe, the distribution, host-plant range, parasites and number of generations of Ostrinia nubilalis were studied 80 years ago by Thompson and Parker during a remarkable survey from 1919 to 1926 (Thompson and Parker, 1928). The ECB was found on several host plants but its favored hosts were undoubtedly maize (Z. mays) and mugwort (A. vulgaris). Although widely distributed in Europe, mugwort was not infested in southern France and northern Italy even if the ECB was common on corn; ECB colonization of this host plant was observed mostly in northern France, northern Germany and Belgium.

The results of our year 2000 sampling in France are consistent with a northern European location for ECB on mugwort. All sites located in northern France were infested with ECB. Conversely, mugwort was rarely infested with ECB in western and eastern France and none of the four sites in the south of France was infested. Our results, together with those of Thompson and Parker (1928), suggest that the geographical distribution of ECB on mugwort has been stable for a number of years. The absence of ECB on mugwort in southern Europe is not because of a lower density of the host plant because $A$. vulgaris is widespread throughout Europe (Thompson and Parker, 1928). Instead, it may be a consequence of environmental conditions having an effect either on the plant or directly on the ECB larvae (hygrometry and temperature).

The geographical distribution of ECB on maize was very different. Maize is widely cultivated in France and infestations, although unequal, have been recorded in all regions except western France. The highest infestations are generally recorded in the southwest, central and eastern regions of France. Conversely, unpredictable but low levels of damage to corn are often reported in northern regions, where mugwort is commonly, if not systematically, infested with ECB.

\section{Population genetics structure and host-plant} differentiation

The populations feeding on the two host plants had markedly different genetic structures. $F_{\text {st }}$ analysis of allozyme frequencies showed a higher level of differentiation within the mugwort group $(\hat{\theta}$-within mugwort $=0.036)$ than within the maize group $(\hat{\theta}$-within maize $=0.009$ ). In the mugwort group, the mtDNA estimate of population structure $\left(F_{\mathrm{st}}=0.038\right)$ was congruent with the nuclear estimate. Conversely, in the maize group, the mtDNA estimate of population structure $\left(F_{\mathrm{st}}=0.039\right)$ was greater than the nuclear estimate, possibly reflecting the greater tendency toward drift of mitochondrial genomes as a result of their maternal mode of inheritance and haploid nature.

The genetic differentiation between the two host groups $(\hat{\theta}$-host $=0.044)$, calculated from allozyme data, indicated that the maize and mugwort groups were different (Table 2). Thus, the differentiation reported by Bourguet et al (2000b) on a regional scale seems to be a general feature over a broader geographical range. 
Host-associated genetic differentiation has already been documented in other moth families such as the Noctuidae (Pashley, 1986), Tortricidae (Emelianov et al, 1995) and Prodoxidae (Groman and Pellmyr, 2000). Populations of $O$. nubilalis differ in terms of pheromone blends ( $\mathrm{E}$ vs $\mathrm{Z}$ ) and voltinism (uni- vs bivoltine) (Hudon et al, 1989). Our results show that populations may also be distinguished on the basis of the type of host plant colonized (maize vs mugwort). Some relationships between these biological characteristics have already been observed. In New York State, three races have been described: bivoltine $\mathrm{Z}$ (BZ), univoltine Z (UZ) and bivoltine E (BE) (Roelofs et al, 1985). The $\mathrm{BE}$ race was found to injure more apple shoots and snap beans than the BZ and UZ races (Straub et al, 1986; Eckenrode and Webb, 1989). McLeod (1981) also noted differential infestations of bivoltine and univoltine populations on sweet pepper, Capsicum frutescens L. Unfortunately the diapausing ECB larvae sampled for the present study were frozen without determining the voltinism and pheromonal status of the populations collected on the two host plants. The precise relationships between biological parameters and host-plant colonization of the populations located in northern France are currently under investigation.

\section{Host-plant-dependent selection}

To date, allozyme studies of ECB have revealed that only the Tpi sex-linked locus displays clear differences in allele frequency between the BE, UZ and BZ races (Glover et al, 1991). The distribution of alleles at the Tpi locus is probably moulded by natural selection because this locus is closely linked to genes involved in the male behavioral response to female pheromones and to genes responsible for differences in voltinism (Glover et al, 1990, 1992). The Tpi locus showed no genetic differentiation between host groups but displayed a highly significant deficit in heterozygotes over the 16 sampling sites. This result may be the consequence of (i) a selection pressure acting on this locus or on linked loci, (ii) a Wahlund effect at the Tpi locus notably if $\mathrm{E}$ and $\mathrm{Z}$ populations of ECB were segregating on mugwort and (iii) the presence of null alleles.

The Mpi locus, which is located in a different region of the genome, also displayed a significant deficit in heterozygotes over the 16 samples collected on mugwort. This locus also showed greater betweengroup $(\hat{\theta}$-host $=0.122)$ than within-group $(\hat{\theta}$-within mugwort $=0.040$ and $\hat{\theta}$-within maize $=0.013)$ differentiation. This greater differentiation at the Mpi locus has already been shown for northern France $(\hat{\theta}$-host $=0.114$ in Bourguet et al, 2000b). Such a consistent allele frequency difference over space and time suggests host-dependent selection acting on Mpi or on linked loci.

Other examples of two populations of the same species inhabiting the same geographical area and yet displaying differentiation include the pea aphid Acyrthosiphon pisum (Via, 1999) and the fruit fly Rhagoletis pomonella (Walsh) (Feder et al, 1988). In this latter species, there is selective maintenance of sympatric host-plant races differing at six allozyme loci mapping to three different regions of the genome (Feder et al, 1997; Filchak et al, 2000).
Gene flow within- and between-host groups

Analysis of the spatial patterns of within- and betweengroup genetic differentiation can provide an indication as to the extent of gene flow within and between the two host groups. For each group, the slope of the regression between genetic and geographic distances can be used to estimate $1 /\left(4 D_{\mathrm{e}} \cdot \pi \sigma^{2}\right)$, where $D_{\mathrm{e}}$ is the effective density of individuals (see Rousset, 1999b) and $\sigma^{2}$ is the onedimensional mean-squared parent offspring distance (Rousset, 1997). In mugwort-feeding populations, the slope of the regression between geographic and genetic distances was 0.0163 (significantly different from 0) giving an estimate of $D_{\mathrm{e}} \cdot \sigma^{2} \sim 5$ moths. Assuming a density of 5 individuals $/ \mathrm{km}^{2}$ - which is certainly a conservative assumption $-\sigma$ equals $1 \mathrm{~km} / \mathrm{gen}^{1 / 2}$. In maize-feeding populations, the isolation by distance was not significant, with a slope of 0.0020 . The estimate of $D_{\mathrm{e}} \cdot \sigma^{2}$ is $\sim 40$ moths. The difference between the two hostplant groups may be because of a difference in $D_{\mathrm{e}}$ rather than a difference in migration. Indeed, because of the intensive cultivation of maize, ECB density is probably much higher on maize than on mugwort.

When isolation by distance analysis was performed for all pairs of populations, one from each host, the slope was not significantly different from zero; betweengroup differentiation, which was slightly higher than within-group differentiations, remained constant at all geographical scales (Figure 2). This was not only the consequence of the host-plant-associated differentiation at the Mpi locus since the same pattern was found when this locus was excluded from the analysis (Figure 2). A similar result was reported by Hardy and Vekemans (2001), who studied allozyme variation in diploid and tetraploid knapweeds, Centaurea jacea L. This pattern is not expected if gene flow was homogenizing allele frequencies between neighboring populations on different hosts. We therefore conclude that there must be barriers to gene exchange between populations feeding on the two host plants. Although the actual level of gene flow cannot be evaluated, equation (A5) and the numerical examples in Figure 3 of Rousset (1999a) suggest that a $1 \%$ introgression rate per generation between the host races would be sufficient to erode any host-associated differentiation between pairs of populations separated by more than a few times $\sigma$ (a few kilometers here). Gene flow between the two host groups is not necessarily the same across the genome. Indeed, recently diverged taxa that remain incompletely isolated reproductively may be permeable to introgression over a large portion of their genome (Ting et al, 2000). Hence, although barriers to gene flow may be quite intense for some regions (eg the region surrounding Mpi), substantial gene flow can still occur in other portion of the genome.

\section{Implications for pest management strategy}

The ECB is the main pest of maize in Europe and North America (Krattiger, 1997). To control this species, transgenic maize varieties have been developed that produce toxins from the bacterium Bacillus thuringiensis (referred to as $B t$ maize). The increasing use of these $B t$ maize varieties generates pressure for the selection of resistance mechanisms in natural populations of ECB (Gould, 1998; Wolfenbarger and Phifer, 2000). This has led to the development of management strategies to 
delay the appearance of resistance to $B t$ toxins (eg Alstad and Andow, 1995, but see Ives, 1996; Peck et al, 1999). All these strategies are based on the use of refuges - non- $B t$ maize planted and maintained in close proximity to $B t$ maize (Gould, 1998). The principle underlying this system of resistance management is that any resistant insects emerging from $B t$ maize are more likely to mate with one of the much larger number of susceptible adult pest insects emerging from the refuges than with each other, thereby decreasing the selection of $B t$ resistance alleles. Gould (1998) suggested that, for some generalist pest species, wild hosts and other crops could serve as part of a larger refuge. However, to be considered as complementary or alternative refuges, these plants must host ECB populations that will randomly mate with those emerging from maize. The geographical distribution and genetic differentiation of ECB growing on mugwort show that adults emerging from this weed are unlikely to delay the evolution of resistance to $B$. thuringiensis toxins. This does not rule out the possibility that other weeds or crops may be useful refuges. However, in the absence of such data, refuges of non-transgenic maize should be planted, to extend the durability of $B t$ maize.

\section{Acknowledgements}

We thank Christophe Buisson for sampling, Simon Moyal and Alexandra Maros for help with mitotype characterization and Richard Harrison, Michel Marchal, Patricia Nel and Frédérique Viard and one anonymous reviewer for helpful comments. This work was supported by the INRA AIP 'Organismes Génétiquement Modifiés et Environnement' and by the MENRT A.O. 'Impact des OGM'. This is publication ISEM No. [20]02-081.

\section{References}

Alstad D, Andow DA (1995). Managing the evolution of insect resistance to transgenic plants. Science 268: 1894-1896.

Anglade EP, Stockel P, IWGO Cooperators (1984). Intraspecific sex-pheromone variability in the European corn borer, Ostrinia nubilalis Hbn. (Lepidoptera, Pyralidae). Agronomie 4: 183-187.

Berembaum M (1996). Introduction to the symposium: on the evolution of specialization. Am Nat 148(Suppl): S78-S83.

Bourguet D, Bethenod M-T, Pasteur N, Viard F (2000a). Gene flow in the European corn borer Ostrinia nubilalis: implications for the sustainability of transgenic insecticidal maize. Proc R Soc London B 267: 117-122.

Bourguet D, Bethenod M-T, Trouvé C, Viard F (2000b). Hostplant diversity of the European corn borer Ostrinia nubilalis: what value for sustainable transgenic insecticidal $B t$ maize. Proc R Soc London B 267: 1177-1184.

Bush GL (1994). Sympatric speciation in animals: new wine in old bottles. Trends Ecol Evol 9: 285-288.

Caffrey DJ, Worthley LH (1927). A progress report on the investigations of the European corn borer. USDA Bulletin 1476, Washington, DC.

Cardé RT, Roelofs WL, Harrison RG, Vawter AT, Brussard PF, Mutuura A, Munroe E (1978). European corn borer: pheromone polymorphism or sibling species? Science 199: 555-556.

Caterino MS, Reed RD, Kuo MM, Sperling FAH (2001). A partitioned likelihood analysis of swallowtail phylogeny (Lepidoptera: Papilionidae). Syst Biol 50: 106-127.
Dieckmann U, Doebeli M (1999). On the origin of species by sympatric speciation. Nature 400: 354-357.

Diehl SR, Bush GL (1989). The role of habitat preference in adaptation and speciation. In: Otte D, Endler JA (eds) Speciation and its Consequence, Sinauer: Sunderland, MA, pp 345-365.

Eckenrode CJ, Webb DR (1989). Establishment of various European corn borer (Lepidoptera: Pyralidae) races on selected cultivars of snap beans. J Econ Entomol 82: 1169-1173.

Emelianov I, Mallet J, Baltensweiler W (1995). Genetic differentiation in Zeiraphera diniana (Lepidoptera, Tortricidae, the larch budmoth): polymorphism, host races or sibling species. Heredity 75: 416-424.

Estoup A, Lagiader RC, Perrot E, Chourrout D (1996). Rapid one-tube DNA extraction for reliable PCR detection of fish polymorphic markers and transgenes. Mol Mar Biol Biotech 5: 295-298.

Excoffier L, Smouse PE, Quattro JM (1992). Analysis of molecular variance inferred from metric distances among DNA haplotypes: application to human mitochondrial DNA restriction data. Genetics 131: 479-491.

Feder JL, Chilcote CA, Bush GL (1988). Genetic differentiation between sympatric host races of the apple maggot fly Rhagoletis pomonella. Nature 336: 61-64.

Feder JL, Roethele JB, Wlazlo B, Berlocher SH (1997). Selective maintenance of allozyme differences among sympatric host races of the apple maggot fly. Proc Natl Acad Sci USA 94: 11 417-11 421 .

Filchak KE, Roethele JB, Feder JL (2000). Natural selection and sympatric divergence in the apple maggot Rhagoletis pomonella. Nature 407: 739-742.

Glover TJ, Campbell M, Robbins PS, Roelofs WL (1990). Sexlinked control of sex pheromone behavioral responses in European corn-borer moths (Ostrinia nubilalis) confirmed with TPI marker gene. Arch Insect Biochem Physiol 15: 67-77.

Glover TJ, Knodel JJ, Robbins PS, Eckenrode CJ, Roelofs WL (1991). Gene flow among three races of European corn borers (Lepidoptera: Pyralidae) in New York State. J Econ Entomol 20: $1356-1362$

Glover TJ, Robbins PS, Eckenrode CJ, Roelofs WL (1992). Genetic control of voltinism characteristics in European corn borer races assessed with a marker gene. Arch Insect Biochem Physiol 20: 107-117.

Goudet J (1999). FSTAT, a program to estimate and test gene diversities and fixation indices (version 2.8). Updated from Goudet J (1995). FSTAT (vers. 1.2): a computer program to calculate F-statistics. J Hered 86: 485-486.

Gould F (1998). Sustainability of transgenic insecticidal cultivars: integrating pest genetics and ecology. Annu Rev Entomol 43: 701-726.

Groman JD, Pellmyr O (2000). Rapid evolution and specialization following host colonization in a yucca moth. J Evol Biol 13: $223-236$.

Hardy OJ, Vekemans X (2001). Patterns of allozyme variation in diploid and tetraploid Centaurea jacea at different spatial scales. Evolution 55: 943-954.

Harrison RG, Vawter AT (1977). Allozyme differentiation between pheromone strains of the European corn borer Ostrinia nubilalis. Ann Entomol Soc Am 70: 717-720.

Holm S (1979). A simple sequentially rejective multiple test procedure. Scand J Statist 6: 65-70.

Hudon M, LeRoux EJ, Harcourt DG (1989). Seventy years of European corn borer (Ostrinia nubilalis) research in North America. Agric Zool Rev 3: 53-96.

Ives AR (1996). Evolution of insect resistance to Bacillus thuringiensis-transformed plants. Science 273: 1412-1413.

Kawecki TJ (1997). Sympatric speciation via habitat specialization driven by deleterious mutations. Evolution 51: 17511763.

Kim C-G, Hoshizaki S, Huang Y-P, Tatsuki S, Ishikawa Y (1999). Usefulness of mitochondrial COII gene sequences in examining phylogenetic relationships in the Asian corn borer, 
Ostrinia furnacalis, and allied species (Lepidoptera: Pyralidae). Appl Entomol Zool 34: 405-412.

Kirkpatrick M, Ravigné V (2002). Speciation by natural and sexual selection. Am Nat 159: S22-S35.

Kondrashov AS, Kondrashov FA (1999). Interactions among quantitative traits in the course of sympatric speciation. Nature 400: 351-354.

Krattiger AF (1997). Insect resistance in crops: a case study of Bacillus thuringiensis (Bt) and its transfer to developing countries. ISAAA Briefs No. 2. ISAAA, Ithaca, NY, p 42.

McLeod DGR (1981). Damage to sweet pepper in Ontario by three strains of European corn borer, Ostrinia nubilalis. Proc Entomol Soc Ont 112: 29-32.

Miller MP (1997). Tools for population genetic analysis (TFPGA 1.3): a windows program for the analysis of allozyme and molecular population genetic data. Computer software distributed by author.

Mutuura A, Munroe E (1970). Taxonomy and distribution of the European corn borer and allied species: genus Ostrinia (Lepidoptera: Pyralidae). In: Pielou DP (eds) Memoirs of the Entomological Society of Canada, Entomological Society of Canada: Ottawa. pp 1-112.

Ostlie KR, Hutchinson WD, Hellmich RL (1997). Bt corn and European corn borer, NCR Publication 602. University of Minnesota, St Paul, MN.

Pashley DP (1986). Host associated genetic differentiation in fall armyworm (Lepidoptera: Noctuidae): a sibling species complex? Ann Entomol Soc Am 79: 898-904.

Pasteur N, Pasteur G, Bonhomme F, Catalan J, Britton-Davidian J (1987). Manuel Technique de Génétique par Electrophorèse des Protéines. Lavoisier: Paris.

Peck SL, Gould F, Ellner SP (1999). Spread of resistance in spatially extended regions of transgenic cotton: implications for management of Heliothis virescens (Lepidoptera: Noctuidae). J Econ Entomol 92: 1-16.

Raymond M, Rousset F (1995). GENEPOP (version 1.2): population genetics software for exact tests and ecumenicism. J Hered 86: 248-249.

Rice WR (1987). Speciation via habitat specialization: the evolution of reproductive isolation as a correlated character Evol Ecol 1: 301-314.

Roelofs WL, Du JW, Tang XH, Robbins PS, Eckenrode CJ (1985). Three European corn borer populations in New York based on sex pheromones and voltinism. J Chem Ecol 11: 829-836.
Rousset F (1997). Genetic differentiation and estimation of gene flow from $F$-statistics under isolation by distance. Genetics 145: 1219-1228.

Rousset F (1999a). Genetic differentiation within and between two habitats. Genetics 151: 397-407.

Rousset F (1999b). Genetic differentiation in populations with different classes of individuals. Theor Popul Biol 55: 297-308.

Schneider S, Roessli D, Excoffier L (2000). Arlequin ver. 2.000: A software for population genetics data analysis. Genetics and Biometry Laboratory, University of Geneva, Switzerland.

Schilthuizen M (2000). Dualism and conflicts in understanding speciation. BioEssays 22: 1134-1141.

Schluter D (1998). Ecological causes of speciation. In: Howard DJ, Berlocher SH (eds) Endless Forms: Species and Speciation, Oxford University Press: New York. pp 114-129.

Straub RW, Weires RW, Eckenrode CJ (1986). Damage to apple cultivars by races of European corn borer (Lepidoptera: Pyralidae). J Econ Entomol 79: 359-363.

Thompson WR, Parker HL (1928). The European corn borer and its controlling factors in Europe. Tech Bull USDA. 59: 1-62.

Ting C-T, Tsaur S-C, Wu C-I (2000). The phylogeny of closely related species as revealed by the genealogy of a speciation gene, odysseus. Proc Natl Acad Sci USA 97: 5313-5316.

Tregenza T, Bridle JR (1998). The diversity of speciation. Trends Ecol Evol 12: 382-383.

Via S (1999). Reproductive isolation between sympatric races of pea aphids. I. Gene flow restriction and habitat choice. Evolution 53: 1446-1457.

Via S (2001). Sympatric speciation in animals: the ugly duckling grows up. Trends Ecol Evol 16: 381-390.

Weir BS, Cockerham CC (1984). Estimating F-statistics for the analysis of population structure. Evolution 38: 1358-1370.

Willett CS, Harrison RG (1999). Insights into genome differentiation: pheromone-binding protein variation and population history in the European corn borer (Ostrinia nubilalis). Genetics 153: 1743-1751.

Wolfenbarger LL, Phifer PR (2000). Biotechnology and ecology the ecological risks and benefits of genetically engineered plants. Science 290: 2088-2093.

Wright S (1943). Isolation by distance. Genetics 28: 139-156.

\section{Appendix}

Allele frequencies at the five allozyme loci for each of 25 populations studied (16 on mugwort and 9 on maize). 
Table 3

Host plant

Allozyme locus

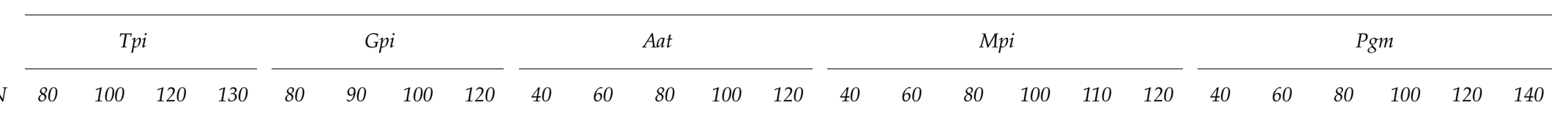

$N \quad 80 \quad 100 \quad 120 \quad 130 \quad 80-90$

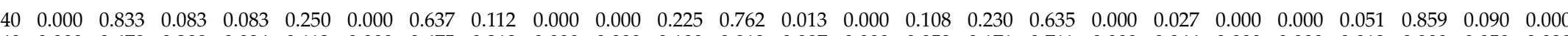
$\begin{array}{lllllllllllllllllllllllllllll}\text { Meu } & 40 & 0.000 & 0.678 & 0.288 & 0.034 & 0.112 & 0.000 & 0.675 & 0.213 & 0.000 & 0.000 & 0.100 & 0.813 & 0.087 & 0.000 & 0.053 & 0.171 & 0.711 & 0.000 & 0.066 & 0.000 & 0.000 & 0.013 & 0.900 & 0.050 & 0.038\end{array}$ $\begin{array}{lllllllllllllllllllllllllll}\text { Sal } & 38 & 0.000 & 0.923 & 0.058 & 0.019 & 0.224 & 0.000 & 0.592 & 0.184 & 0.000 & 0.000 & 0.184 & 0.816 & 0.000 & 0.000 & 0.027 & 0.108 & 0.838 & 0.000 & 0.027 & 0.000 & 0.000 & 0.000 & 0.855 & 0.145 & 0.000\end{array}$ $\begin{array}{lllllllllllllllllllllllllll}\text { Wai } & 40 & 0.000 & 0.967 & 0.033 & 0.000 & 0.050 & 0.000 & 0.650 & 0.300 & 0.000 & 0.000 & 0.188 & 0.762 & 0.050 & 0.039 & 0.000 & 0.118 & 0.658 & 0.000 & 0.184 & 0.000 & 0.000 & 0.025 & 0.813 & 0.125 & 0.038\end{array}$ $\begin{array}{lllllllllllllllllllllllllllllll}\text { Kra } & 24 & 0.000 & 0.778 & 0.222 & 0.000 & 0.083 & 0.000 & 0.542 & 0.375 & 0.000 & 0.000 & 0.021 & 0.896 & 0.083 & 0.021 & 0.000 & 0.146 & 0.771 & 0.000 & 0.063 & 0.000 & 0.000 & 0.000 & 0.659 & 0.341 & 0.000\end{array}$ $\begin{array}{lllllllllllllllllllllllllllll}\text { Ven } & 40 & 0.000 & 0.603 & 0.310 & 0.086 & 0.075 & 0.000 & 0.863 & 0.063 & 0.000 & 0.000 & 0.087 & 0.825 & 0.087 & 0.000 & 0.053 & 0.039 & 0.803 & 0.000 & 0.105 & 0.000 & 0.000 & 0.063 & 0.900 & 0.025 & 0.013\end{array}$ $\begin{array}{llllllllllllllllllllllllllllll}\text { Thi } & 20 & 0.000 & 0.531 & 0.313 & 0.156 & 0.050 & 0.000 & 0.900 & 0.050 & 0.000 & 0.000 & 0.100 & 0.875 & 0.025 & 0.000 & 0.026 & 0.158 & 0.763 & 0.000 & 0.053 & 0.000 & 0.000 & 0.025 & 0.850 & 0.050 & 0.075\end{array}$ $\begin{array}{lllllllllllllllllllllllllllll}\text { Grg } & 39 & 0.000 & 0.759 & 0.056 & 0.185 & 0.244 & 0.000 & 0.603 & 0.154 & 0.000 & 0.000 & 0.167 & 0.782 & 0.051 & 0.000 & 0.108 & 0.081 & 0.811 & 0.000 & 0.000 & 0.000 & 0.000 & 0.038 & 0.808 & 0.128 & 0.026\end{array}$ $\begin{array}{llllllllllllllllllllllllllllllll}\text { Geu } & 28 & 0.000 & 0.756 & 0.220 & 0.024 & 0.071 & 0.000 & 0.607 & 0.321 & 0.000 & 0.000 & 0.036 & 0.893 & 0.071 & 0.000 & 0.071 & 0.000 & 0.875 & 0.000 & 0.054 & 0.000 & 0.000 & 0.018 & 0.929 & 0.036 & 0.018\end{array}$ $\begin{array}{llllllllllllllllllllllllllllll}\text { Cap } & 37 & 0.000 & 0.944 & 0.056 & 0.000 & 0.054 & 0.000 & 0.757 & 0.189 & 0.000 & 0.000 & 0.095 & 0.905 & 0.000 & 0.027 & 0.027 & 0.149 & 0.743 & 0.000 & 0.054 & 0.000 & 0.000 & 0.014 & 0.903 & 0.056 & 0.028\end{array}$ $\begin{array}{lllllllllllllllllllllllllll}\text { Ver } & 40 & 0.000 & 0.935 & 0.032 & 0.032 & 0.100 & 0.000 & 0.738 & 0.162 & 0.000 & 0.000 & 0.038 & 0.938 & 0.025 & 0.000 & 0.063 & 0.025 & 0.825 & 0.000 & 0.087 & 0.000 & 0.000 & 0.050 & 0.875 & 0.063 & 0.013\end{array}$ $\begin{array}{lllllllllllllllllllllllllll}\text { Moy } & 40 & 0.000 & 0.656 & 0.250 & 0.094 & 0.150 & 0.000 & 0.700 & 0.150 & 0.000 & 0.000 & 0.138 & 0.825 & 0.038 & 0.000 & 0.013 & 0.125 & 0.762 & 0.000 & 0.100 & 0.000 & 0.000 & 0.090 & 0.808 & 0.103 & 0.000\end{array}$ $\begin{array}{lllllllllllllllllllllllllllll}\text { Stee } & 40 & 0.000 & 0.930 & 0.070 & 0.000 & 0.100 & 0.013 & 0.563 & 0.325 & 0.000 & 0.000 & 0.103 & 0.821 & 0.077 & 0.000 & 0.038 & 0.063 & 0.825 & 0.000 & 0.075 & 0.000 & 0.000 & 0.063 & 0.863 & 0.050 & 0.025\end{array}$ $\begin{array}{llllllllllllllllllllllllllll}\text { Sei } & 29 & 0.000 & 0.708 & 0.250 & 0.042 & 0.017 & 0.000 & 0.776 & 0.207 & 0.000 & 0.000 & 0.138 & 0.862 & 0.000 & 0.000 & 0.000 & 0.296 & 0.574 & 0.000 & 0.130 & 0.000 & 0.000 & 0.086 & 0.879 & 0.034 & 0.000\end{array}$

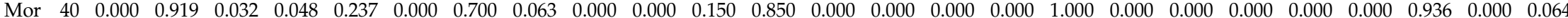

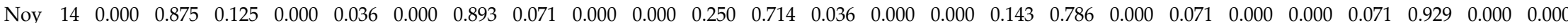
$\begin{array}{llllllllllllllllllllllllllllll}\text { All } & 0.000 & 0.800 & 0.150 & 0.050 & 0.116 & 0.001 & 0.700 & 0.184 & 0.000 & 0.000 & 0.126 & 0.834 & 0.040 & 0.005 & 0.037 & 0.116 & 0.774 & 0.000 & 0.069 & 0.000 & 0.000 & 0.038 & 0.860 & 0.081 & 0.021\end{array}$

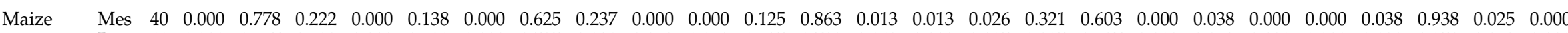
$\begin{array}{llllllllllllllllllllllllllllll}\text { Pic } & 40 & 0.000 & 0.867 & 0.133 & 0.000 & 0.138 & 0.000 & 0.525 & 0.338 & 0.013 & 0.013 & 0.125 & 0.788 & 0.063 & 0.000 & 0.025 & 0.325 & 0.637 & 0.000 & 0.013 & 0.000 & 0.000 & 0.038 & 0.950 & 0.013 & 0.000\end{array}$

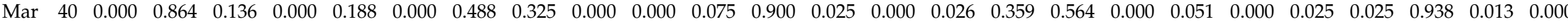

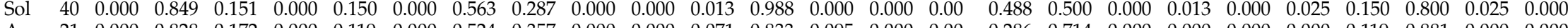
$\begin{array}{lllllllllllllllllllllllllllll}\text { Ave } & 21 & 0.000 & 0.828 & 0.172 & 0.000 & 0.119 & 0.000 & 0.524 & 0.357 & 0.000 & 0.000 & 0.071 & 0.833 & 0.095 & 0.000 & 0.00 & 0.286 & 0.714 & 0.000 & 0.000 & 0.000 & 0.000 & 0.119 & 0.881 & 0.000 & 0.000\end{array}$

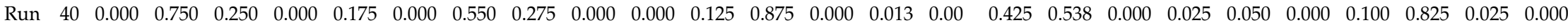
$\begin{array}{lllllllllllllllllllllllllll}\text { Wol } & 40 & 0.066 & 0.820 & 0.115 & 0.000 & 0.150 & 0.000 & 0.625 & 0.225 & 0.000 & 0.000 & 0.100 & 0.825 & 0.075 & 0.000 & 0.038 & 0.325 & 0.625 & 0.000 & 0.013 & 0.000 & 0.000 & 0.025 & 0.962 & 0.013 & 0.000\end{array}$ $\begin{array}{llllllllllllllllllllllllllll}\text { Lor } & 40 & 0.000 & 0.789 & 0.211 & 0.000 & 0.075 & 0.000 & 0.600 & 0.325 & 0.000 & 0.000 & 0.162 & 0.825 & 0.013 & 0.013 & 0.038 & 0.513 & 0.387 & 0.000 & 0.050 & 0.000 & 0.000 & 0.038 & 0.962 & 0.000 & 0.000\end{array}$ $\begin{array}{llllllllllllllllllllllllllllll}\text { Ger } & 49 & 0.000 & 0.797 & 0.203 & 0.000 & 0.102 & 0.000 & 0.643 & 0.255 & 0.000 & 0.000 & 0.061 & 0.929 & 0.010 & 0.000 & 0.020 & 0.398 & 0.541 & 0.010 & 0.031 & 0.000 & 0.010 & 0.010 & 0.969 & 0.010 & 0.000\end{array}$ $\begin{array}{lllllllllllllllllllllllllllllll}\text { All } & 0.007 & 0.816 & 0.177 & 0.000 & 0.137 & 0.000 & 0.571 & 0.292 & 0.001 & 0.001 & 0.095 & 0.870 & 0.033 & 0.004 & 0.019 & 0.382 & 0.568 & 0.001 & 0.026 & 0.006 & 0.007 & 0.060 & 0.914 & 0.014 & 0.000\end{array}$ 